\title{
The development of a competitive PCR-ELISA for the detection of equine herpesvirus-1
}

\author{
P. Daly, S. Doyle* \\ National Institute for Cellular Biotechnology, Department of Biology, National University of Ireland, Maynooth Co., Kildare, Ireland
}

Received 12 June 2002; received in revised form 10 October 2002; accepted 11 October 2002

\begin{abstract}
Equine herpesvirus-1 (EHV-1) infection is of significant animal welfare and economic importance. Yet, no standardised molecular techniques are available for diagnosis or confirmation of viral infection. The purpose of this study was to develop a standardised and quantitative assay system for the reliable detection of EHV-1 infection which was capable of eliminating the likelihood of false negative results. A region within the EHV-1 glycoprotein B gene was amplified by polymerase chain reaction (PCR), cloned and subjected to site-directed mutagenesis to generate a control plasmid, amplifiable by identical primers to wild type EHV-1, yet capable of detection by an alternate dinitrophenylated oligonucleotide probe in a PCR-ELISA system. A competitive PCR-ELISA system which can control for the presence of PCR inhibitors and which is capable of detecting 63 genome equivalents of EHV-1 has been developed. EHV-1 presence in infected equine tissue and cell culture material was demonstrated using this system. The entire assay can be completed within one working day and facilitates multiple sample analysis. The availability of a robust, competitive PCR-ELISA system for the detection of EHV-1 will facilitate the rapid and sensitive detection of EHV-1 and offers the potential for eliminating the occurrence of abortion storms in stud farms.
\end{abstract}

(C) 2002 Elsevier Science B.V. All rights reserved.

Keywords: Fetal; Diagnosis; Oligonucleotides; Immunoassay; Molecular diagnostics

\section{Introduction}

The alphaherpesvirus, equine herpesvirus-1 (EHV-1), is the causative agent of respiratory disease, abortion and neurological disorders in horses (Allen and Bryans 1986; Crabb and Studdert, 1995). Originally EHV-1 was designated as rhinopneumonitis virus, however examination of restriction endonuclease DNA fingerprints by Studdert et al. (1981) showed two distinct virus subtypes namely EHV-1 and EHV-4. While EHV-4 is restricted to the respiratory epithelium and lymph nodes draining the lung, EHV-1 is distinct in that it spreads systemically resulting in post-respiratory complications including abortion and paralysis (Wagner et al., 1992; Lawrence et al., 1994). Due to the ability of EHV-1 to cause 'abortion storms' in mares after fetal infection (Studdert and Blackney 1979; Crabb and Studdert, 1995) diag-

\footnotetext{
* Corresponding author. Tel.: +353-1-7083858; fax: +353-17083845

E-mail address: sean.doyle@may.ie (S. Doyle).
}

nosis of EHV-1 must be rapid and sensitive so that early intervention policies, aimed at reducing the effect of virus spread, can be put in place (Ballagi-Pordany et al., 1990; Sharma et al., 1992; Lawrence et al., 1994; Gupta et al., 1996).

The development of the polymerase chain reaction (PCR) has lead to improved detection of EHV-1 DNA from clinical and cell culture material (Kirisawa et al., 1993). Amplification of viral DNA by PCR can be further enhanced by hybridisation with viral specific DNA probes (Lawrence et al., 1994; Welch et al., 1992; Kirisawa et al., 1993) and also by restriction endonuclease digestion (Allen et al., 1983; Morris and Field, 1988; Palfi and Christensen, 1995). However, the extraction of viral DNA from samples may also lead to the co-purification of PCR inhibitors (Zerbini et al., 1999). The presence of inhibitory molecules in a PCR reaction suppress $T a q$ polymerase activity, preventing the amplification of viral DNA and thus leads to false negative results (Barber et al., 1999). A method of determining the presence of PCR inhibitors is co- 
amplification of a control plasmid with the target DNA using identical primers pairs (Barber et al., 1999; Zerbini et al., 1999; Drews et al., 2000). The control plasmid contains a short mutagenised DNA sequence and amplicons of target and control can be distinguished from each other, post-PCR, using type-specific oligonucleotide probes in an ELISA.

In the present study, the development of a robust competitive PCR-ELISA system for the detection of EHV-1 is described. The control plasmid was constructed by the introduction of a heterogeneous dinitrophenol (DNP)-labelled oligonucleotide probe sequence by site-directed mutagenesis (SDM). The rapid, competitive PCR-ELISA assay displayed high levels of sensitivity and specificity detecting as little as 63 genome equivalents of EHV-1.

\section{Materials and methods}

\subsection{EHV-1 viral strains and viral DNA extraction}

EHV-1 wild type (wt) strain Ab4p (obtained from Dr Josh Slater, Queens Veterinary School Hospital, University of Cambridge, UK) was originally isolated from a field case of abortion and paralysis in a mare and is regarded as a pathogenic strain of EHV-1. The virus was supplied as a concentrated mixture of virus in lysed ED cells with a viral copy number (genome equivalent) of approximately $10^{10}$, as determined by plaque assay. EHV-1 tissue homogenates (provided by Dr Werner Eichhorn, München, Germany) were isolated from fetal liver, lung and spleen. Positive EHV-1 tissue samples (by IF and isolation) were labelled S726-8, S685-7 and 835-7 and negative tissue samples labelled S611-3, S723-5 and 597-9. EHV-1 wt strain Ab4p (5 $\mu$ l lysate) and tissue homogenate $(5 \mu \mathrm{l})$ were extracted using the Qiagen QIAamp spin column DNA midi kit extraction protocol (Qiagen, Hilden, Germany) (final volume: $200 \mu \mathrm{l}$ ). DNA extraction was performed in separate area to that of PCR reagent preparation and nucleic acid amplification.

\subsection{EHV-1 oligonucleotide primers}

The viral DNA was amplified by using specific oligonucleotide primers selected from the glycoprotein $\mathrm{B}$ (gB) region of the EHV-1 genome. The primer sequences were selected based on results obtained by Kirisawa et al. (1993). The 20 base biotinylated (B) forward primer sequence (P1) was compatible with both EHV-1 and EHV-4 while the reverse 20 base sequence (P2) was compatible with only EHV-1. The 5' biotinylated nucleotide sequences for the forward primer $\mathrm{P} 1$ was: 5'-B-CTTGTGAGATCTAACCGCAC-3' and unmodified reverse P2 primer was: 5'-GCGTTATAGCTATCACGTCC-3' (Sigma-Genosys, Cambridge, UK).

\subsection{Amplification of $D N A$}

A total of $5 \mu 1$ of each DNA sample was used in each PCR reaction with $10 \mathrm{mM}$ Tris $-\mathrm{HCl} \mathrm{pH} 9.0,50 \mathrm{mM}$ $\mathrm{KCl}, 0.1 \%$ (v/v) Triton X-100, $1.5 \mathrm{mM} \mathrm{MgCl}_{2}, 200 \mu \mathrm{M}$ of each dNTP (Promega, WI, USA), 1 M Betaine (Sigma, Dorset, UK), $1.0 \mu \mathrm{M}$ of the above primers in a total volume of $49.5 \mu \mathrm{l}$. Hot-start PCR was performed on each sample by adding $0.5 \mu \mathrm{l}$ of $\mathrm{Taq}$ polymerase (Promega) after the initial 6 min denaturation step at $95{ }^{\circ} \mathrm{C}$. The PCR reaction was then continued with 35 cycles consisting of $1 \mathrm{~min}$ denaturation at $95{ }^{\circ} \mathrm{C}$, primer annealing at $55{ }^{\circ} \mathrm{C}$ for $1 \mathrm{~min}$, extension at $72{ }^{\circ} \mathrm{C}$ for 2 min and finally extension for $5 \mathrm{~min}$ at $72{ }^{\circ} \mathrm{C}$. PCR amplified DNA was analysed by agarose gel electrophoresis whereby $10 \mu \mathrm{l}$ of product was ran on $1 \%(\mathrm{w} / \mathrm{v})$ agarose (Promega) containing $0.5 \mu \mathrm{g} / \mathrm{ml}$ of ethidium bromide (Sigma, Dorset) for $30 \mathrm{~min}$ at $100 \mathrm{~V}$. Visualisation of the 460 bp P1-P2 amplicons was performed using an 'Eagle-Eye II' digital still video system (Stratagene, CA, USA).

\subsection{Construction of EHV-1 gB plasmid}

EHV-1 gB P1-P2 amplicons were purified using the Strata Prep PCR purification kit (Stratagene). Purified PCR products were cloned into the pCR-2.1 TOPO vector (Invitrogen, Groningen, NL) following manufacturers' instructions and transformed into competent $E$. coli. Following purification (Qiagen plasmid purification kit, Qiagen), the gB plasmid was subjected to PCR using plasmid-specific M13 primers supplied by the manufacturer and products screened by restriction digestion with Eco RI and BamHI enzymes. The M13 PCR products were sequenced using a Perkin Elmer ABI Prism 310 genetic analyser and sequence homology was determined with that of the known wt EHV-1 gB sequence using the BLAST algorithm (http:// www.ncbi.nlm.nih.gov/blast/bl2seq/bl2.html).

\subsection{Construction of competitive internal control plasmid}

A modification of the method of Barber et al. (1999) for SDM was employed in the design of the control plasmid which involved replacing a $30 \mathrm{bp}$ sequence of the $\mathrm{gB}$ plasmid with a heterogenous sequence of similar $T_{\mathrm{m}}$ and deoxynucleotide composition (Fig. 1). The forward 40-mer primer (mutant DNP) contained the control probe site. The first 10 bases at the $3^{\prime}$ end of the 'mutant DNP' primer was complementary to the EHV-1 $\mathrm{gB}$ sequence while the remaining 30 bases formed a $5^{\prime}$ overhang which incorporated the control probe site (Fig. 1). The sequence of the mutant DNP primer was: 5'-CTCAAGAAGACetgcagTCtetaga GGAACTCCAACGTCA-3' (note: the control probe site in bold). Two

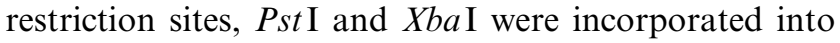




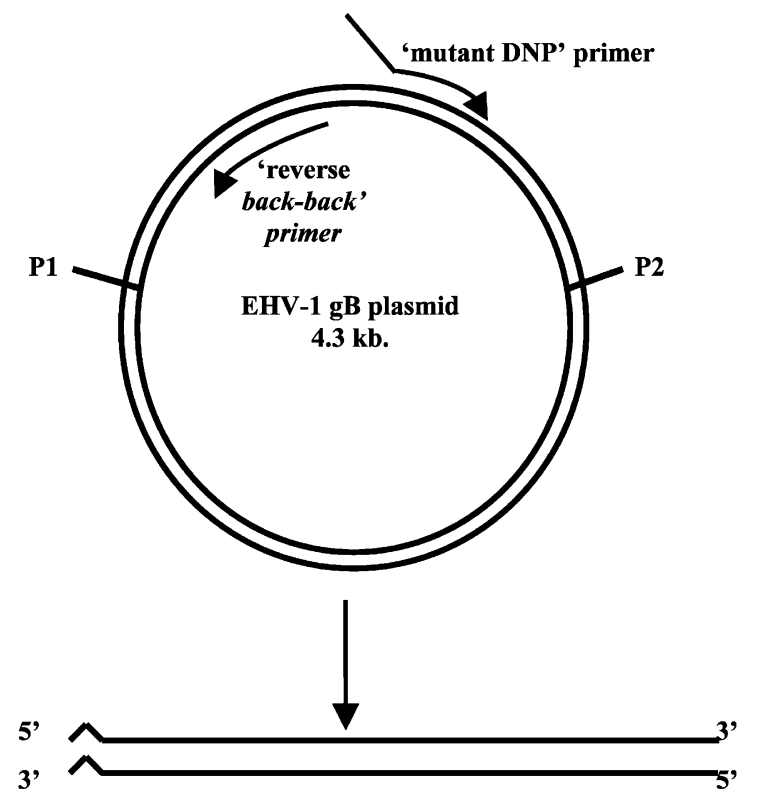

Full 4.3 kb linear vector including new mutated sequence.
Control plasmid purified, amplified by PCR using P1-P2 primers, screened by restriction digestion using $P$ st 1 and $X b a 1$ and finally sequenced.
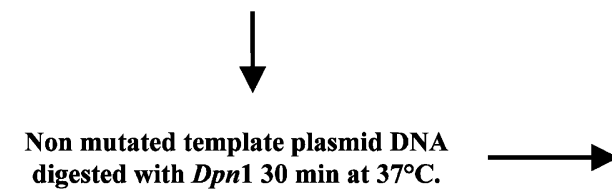

Dpn1 inactivated by heating $7^{\circ} \mathrm{C}$ for $30 \mathrm{~min}$.

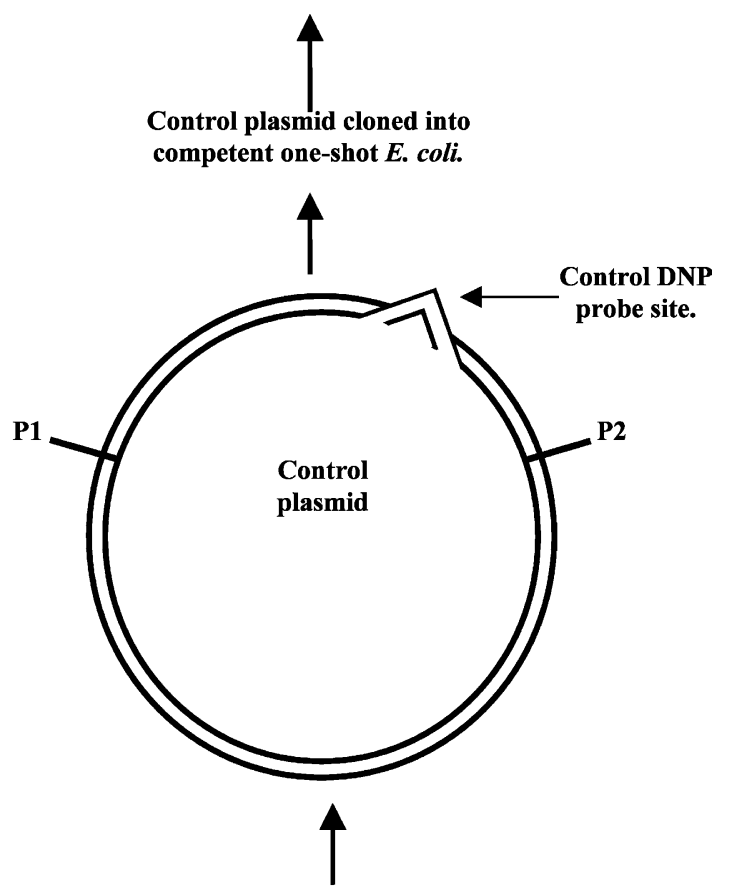
digested with $D p n 130$ min at $37^{\circ} \mathrm{C}$.

Fig. 1. Inverse PCR method for SDM showing the individual steps involved in the generation of a control plasmid. 'Mutant DNP' refers to an oligonucleotide containing a complementary sequence to which the control DNP probe binds.

the control probe sequence, which allowed for selection of control plasmid (shown in small font). The 20-mer 'reverse back-back' primer shown below was phosphorylated at the $5^{\prime}$ end (5'-p-CCTCCACTGCTCGTTTGTGT-3'). Inverse PCR was carried out using $2.5 \mathrm{U}$ of $P f u$ polymerase, in a total volume of $50 \mu \mathrm{l}$ with $1.0 \mu \mathrm{M}$ of each of the above forward 'mutant DNP' and

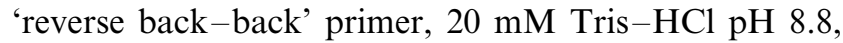
$10 \mathrm{mM} \mathrm{KCl}, 10 \mathrm{mM}(\mathrm{NH} 4)_{2} \mathrm{SO}_{4}, 2 \mathrm{mM} \mathrm{MgSO} 4,0.1 \%$ (v/v) Triton X-100, $5 \mu \mathrm{g}$ BSA, $1.5 \mathrm{mM} \mathrm{MgCl} 2,200 \mu \mathrm{M}$ of each dNTP and $1 \mu \mathrm{l}$ template (gB plasmid: $70 \mu \mathrm{g} / \mathrm{ml}$ ). Cycle conditions were initial 4 min denaturation step at $95{ }^{\circ} \mathrm{C}$. The PCR reaction was then continued with 20 cycles consisting of $1 \mathrm{~min}$ denaturation at $95{ }^{\circ} \mathrm{C}$, primer annealing at $60{ }^{\circ} \mathrm{C}$ for $2 \mathrm{~min}$, extension at $72{ }^{\circ} \mathrm{C}$ for 7 min. Ten microlitre of PCR product was removed and gB plasmid digested for $30 \mathrm{~min}$ at $37{ }^{\circ} \mathrm{C}$ with $D p n \mathrm{I}(10$ $\mathrm{U}$ ) in SuRE/Cut buffer ( $33 \mathrm{mM}$ Tris acetate, $66 \mathrm{mM}$ potassium acetate, $10 \mathrm{mM}$ magnesium acetate, $0.5 \mathrm{mM}$ DTT, pH 7.9). The linear control plasmid was then ligated and cloned into one-shot competent $E$. coli and colonies selected for the presence of the plasmid by PCR using the $\mathrm{P} 1-\mathrm{P} 2$ primers pairs. The control probespecific restriction sites ( $X b a \mathrm{I}$ and $P s t \mathrm{I})$ were subse- quently used to screen and select $\mathrm{P} 1-\mathrm{P} 2$ positive colonies for the correct control probe site sequence.

Purified $\mathrm{gB}$ and control plasmids were diluted $1 / 100$ in sterile water (DNA/RNA free) and the O.D. 260/280 nm measured using a Beckman DU 640 Spectrophotometer. O.D. $260 \times$ dilution factor $\times 50=$ concentration of DNA in $\mu \mathrm{g} / \mathrm{ml}$.

\subsection{PCR-ELISA procedure}

Microwells (Nunc, Roskilde, Denmark) were coated with streptavidin $(2.5 \mu \mathrm{g} / \mathrm{ml})$ and stabilised for $4{ }^{\circ} \mathrm{C}$ storage by the addition of $1 \%(\mathrm{w} / \mathrm{v}) \mathrm{BSA}$ in $50 \mathrm{mM}$ sodium carbonate buffer $\mathrm{pH}$ 9.4. P1-P2 PCR products $(5 \mu \mathrm{l})$ were transferred in duplicate to streptavidin coated microtitre plates in $95 \mu \mathrm{l} 6 \mathrm{X} \mathrm{SSC}(0.9 \mathrm{M} \mathrm{NaCl}$, $0.09 \mathrm{M}$ sodium citrate solution). The biotinylated amplicons were left to attach for $30 \mathrm{~min}$ at $37{ }^{\circ} \mathrm{C}$. Wells were washed twice with phosphate buffered saline containing $0.05 \%$ (v/v) Tween-20 (PBST) and $100 \mu \mathrm{l}$ of melting solution $(0.125 \mathrm{M} \mathrm{NaOH}, 0.1 \mathrm{M} \mathrm{NaCl})$ was added to the microwells to dissociate DNA duplex, incubated at room temperature for $3 \mathrm{~min}$ and washed four times with PBST. Then, $100 \mu 1$ of either the $\mathrm{gB}$ or 
the control complementary DNP oligonucleotide probe $(100 \mathrm{ng} / \mathrm{ml})$ in $6 \mathrm{X} \mathrm{SSC} / 0.1 \%$ (w/v) SDS was hybridised to the biotinylated forward strand at $60{ }^{\circ} \mathrm{C}$ for $1 \mathrm{~h}$ followed by washing four times with PBST. The DNP oligonucleotide probe was designed to be complementary to the $\mathrm{gB}$ or control sequences described above. The DNP probes (OSWEL, Southampton, UK) nucleotide sequences were: $\mathrm{gB}$ probe: $5^{\prime}(\mathrm{DNP})_{3}$-TGACGTTGGAAGAATCGGTACCTGCCATTG-3'; control probe: 5'(DNP) ${ }_{3}$-GTTCCTCTAGAGACTGCAGGTCTTCTTGAG-3'. After hybridisation of the DNP probes wells were washed four times and blocked for $10 \mathrm{~min}$ with $2.5 \%$ (w/v) milk powder in PBST. Following removal of the blocking solution, IgG[anti-DNP]-horseradish peroxidase conjugate was added, incubated at room temperature for $30 \mathrm{~min}$ and washed four times with PBST. Substrate (100 $\mu$ l tetramethylbenzidine) was then added and incubated for $15 \mathrm{~min}$ at room temperature. The reaction was terminated by the addition of $1 \mathrm{~N}$ sulphuric acid and measured spectrophotometrically at 450/630 nm (Dynatech MRX).

\subsection{Competitive PCR-ELISA assay}

Preliminary experiments involved amplification of the $\mathrm{P} 1-\mathrm{P} 2$ fragments from serial dilutions of $\mathrm{gB}$ and control templates in non-competitive assays to determine optimal copy number detection. Assay sensitivity was determined using different probe associations (i.e., gB probe alone, $\mathrm{gB}$ and control probe together and control probe alone). Following optimisation of PCR-ELISA conditions, serial dilutions of $\mathrm{gB}$ plasmid were coamplified with known different amounts of control (data not shown). The selected concentration of control plasmid used in the competitive PCR-ELISA was established by determining optimal levels of $\mathrm{gB}$ target DNA detection whilst not suppressing the detection of the control. Following determination of the optimal control plasmid copy number in the competitive PCR ELISA assay, validation of the assay involved coamplifying 1000 copies of control with purified wt Ab4p EHV-1 and positive/negative EHV-1 fetal liver lung and spleen tissue samples. Finally, a known PCR inhibitor (sodium iodide) was used to assess the efficacy of the competitive control plasmid in the PCR-ELISA.

\section{Results}

\subsection{Generation of $g B$ and internal control plasmids}

The EHV-1 P1-P2 PCR product (460 bp), derived from wt EHV-1 strain Ab4p, was purified and cloned into the pCR-2.1 vector and competent one-shot $E$. coli were subsequently transformed. Resultant M13 forward-reverse amplicons were of the correct size (661 bp) and subsequent digestion with Bam HI and Eco RI yielded 613 and 478 bp products, respectively (data not shown). Sequence analysis of the purified $\mathrm{gB}$ plasmid revealed the correct orientation of the $\mathrm{P} 1-\mathrm{P} 2$ fragment in the pCR-2.1 TOPO vector. PCR and restriction analysis of the plasmid derived from SDM of the $\mathrm{gB}$ plasmid resulted in the generation of the correct $\mathrm{P} 1-\mathrm{P} 2$ amplicon size that was susceptible to digestion with both $X b a \mathrm{I}$ and Pst I (Fig. 2), was thus selected as the internal control plasmid for PCR-ELISA optimisation.

\subsection{Competitive PCR-ELISA}

Serial dilutions of the $\mathrm{gB}$ plasmid from $10^{2}-10^{4}$ copies were amplified in the absence, and presence, of dilutions of control plasmid to determine the minimum copy number of competitor required for detection by PCR ELISA whilst not inhibiting the amplification efficiency of the target. A minimum of 100 molecules of either plasmid was required for reliable detection (Fig. 3 and data not shown). Furthermore, comparable amplification efficiency was recorded between the target and the control at similar copy numbers. Lower copy numbers of each plasmid failed to result in any detectable P1-P2 amplicons by either PCR-ELISA or gel electrophoresis (Fig. 3 and data not shown). A total of 10000 copies of the control when co-amplified with serial dilutions of $\mathrm{gB}$ plasmid caused a reduction in the sensitivity of detection as determined by PCR-ELISA when compared to that of $\mathrm{gB}$ amplified alone (Fig. 3). In contrast, when 1000 copies of control was co-amplified with gB plasmid, no significant difference in amplification efficiency of target $\mathrm{gB}$ in the competitive reaction or when $\mathrm{gB}$ was amplified alone could be detected (Fig. 3). At 1000 copies of control, as low as 100 copies of $\mathrm{gB}$ plasmid were readily detected in the competitive assay and this level of control was subsequently used in the competitive PCR-ELISA. No significant cross-reactivity was observed between $\mathrm{gB} /$ control DNP probe and the $\mathrm{gB} /$ control PCR products as determined by hybridisation of non-homologous probes with amplicons (Fig. 3 and data not shown).

\subsection{Competitive PCR-ELISA assay for the detection of wt EHV-1}

To evaluate the efficiency of the competitive PCR ELISA assay, 1000 copies of control were co-amplified with serial dilutions of extracted wt EHV-1, and tissue samples. All samples were extracted using Qiagen spin columns and subsequently serially diluted to $1 \times 10^{-6}$. Each dilution was amplified alone or co-amplified with 1000 copies of control plasmid. Amplification of individual wt EHV-1 serial dilutions (from a viral stock of $10^{10}$ genome equivalents EHV-1) resulted in endpoint detection at a $10^{-5}$ dilution, which equates to 63 


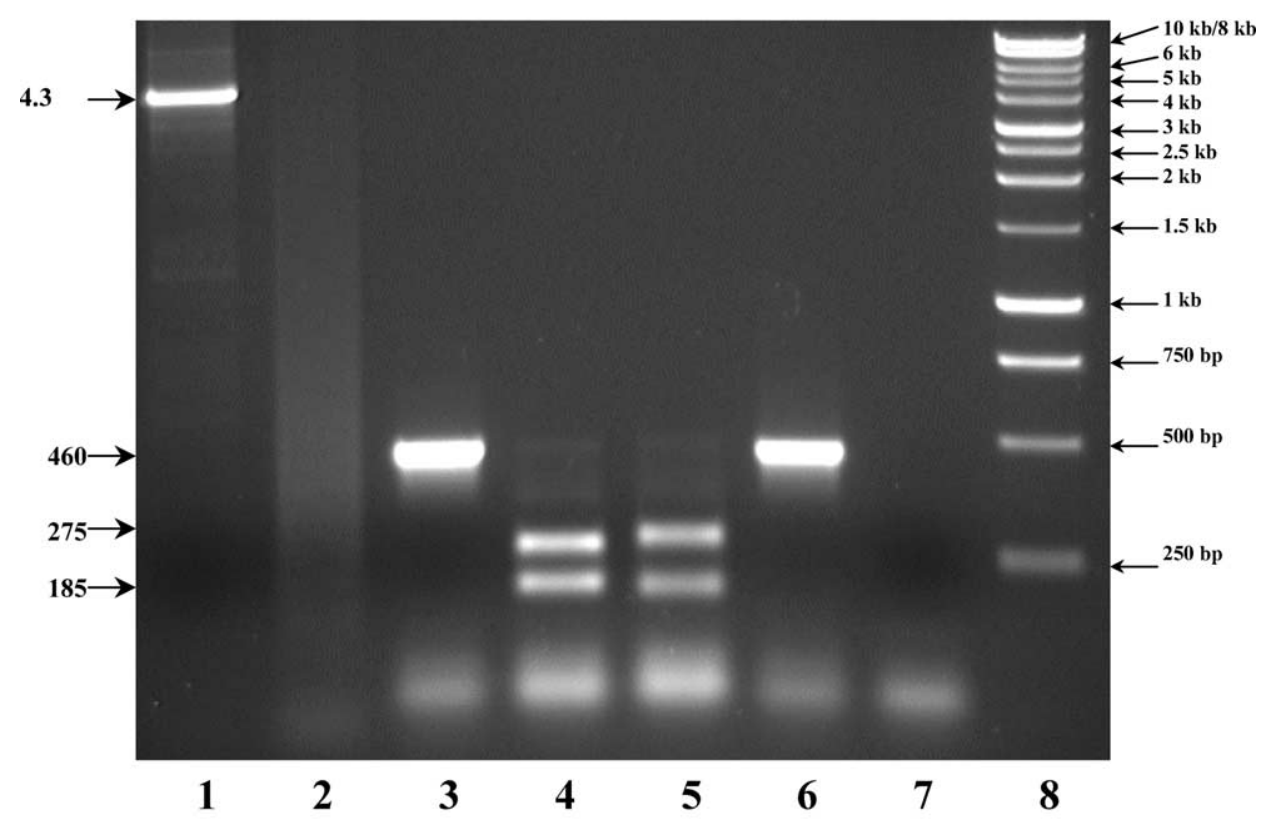

Fig. 2. Analysis of control plasmid and resultant PCR products by agarose gel electrophoresis. Lanes 1-2: DpnI-digested control (lane 1) and gB plasmids (lane 2), respectively; lane 3: P1-P2 PCR product from control plasmid (460 bp); lane 4: XbaI digestion of control P1-P2 amplicon (189 and $271 \mathrm{bp}$ ); lane 5: PstI digestion of control P1-P2 amplicon (185 and $275 \mathrm{bp}$ ); lane 6: P1-P2 PCR product from gB plasmid; lane 7: negative control; Lane 8: $10 \mathrm{~kb}$ molecular weight marker.

genome equivalents of EHV-1 (Fig. 4). In the competitive assay, control amplification was out-competed by the large amounts of wt EHV-1 in the range from neat to $10^{-3}$ dilution. From $10^{-4}$ to $10^{-6}$ wt dilutions, the levels of control amplification increased with decreasing wt concentration. Due to amplification of wt EHV-1 at high concentrations and control at low target levels, these results demonstrate that no PCR inhibitors were present in any of the serial dilutions tested.

\subsection{Validation of the PCR-ELISA}

The competitive PCR-ELISA was validated by examination of EHV-1 positive and negative fetal tissue homogenate samples isolated from fetal liver, lung and spleen. Samples labelled S726-8, S685-7 and 835-7 were positive by PCR-ELISA while samples S611-3, S723-5 and 597-9 were negative (Fig. 5). The results obtained here correlated with gel electrophoresis analysis (data not shown) and immunofluorescent assay/virus isolation studies by Dr Werner Eichhorn (personal communication). Co-amplification of 1000 copies of control with extracted negative EHV-1 tissue samples (S611-3, S7235 and 597-9) resulted in the detection of the control amplicon in all three negative samples (Fig. 5). In the positive tissue samples, control amplification was not observed due to the high template EHV-1 levels which out-competed the control for $\mathrm{P} 1-\mathrm{P} 2$ primer binding. At a concentration of $50 \mathrm{mM} \mathrm{NaI}$, amplification was completely inhibited while at $5 \mathrm{mM} \mathrm{NaI}$, the inhibitory effect was almost completely removed with absorbance values approaching that of control only (Fig. 5).

\section{Discussion}

In this report we describe a rapid and sensitive competitive PCR-ELISA method which can detect 63 genome equivalents of EHV-1 from culture and clinical specimens.

To date, only a limited number of reports detail the relative sensitivities of the oligonucleotide primers in EHV-1 PCR detection assays whereby the sensitivities of the PCR assays using 'hot-start' PCR (Osterrieder et al., 1994) or nested PCR (Kirisawa et al. 1993; Borchers and Slater, 1993) using ethidium bromide/agarose gel electrophoresis detection was 100, 10 copies and 1-3 copies of EHV-1, respectively. In addition, a major complication in the diagnosis of viral infections by PCR is the presence of $T a q$ polymerase inhibitors that lead to false negative results (Courtney et al., 1999; Barber et al., 1999). The presence of such inhibitors can be monitored by the incorporation of a competitive control plasmid (Courtney et al., 1999). Thus, both the target and control are affected equally by variation in amplification efficiency (Drews et al., 2000). Furthermore, the incorporation of a hybridisation probe in an ELISA format generally increases the specificity and sensitivity of the PCR assay and eliminates analysis by gel electrophoresis. 

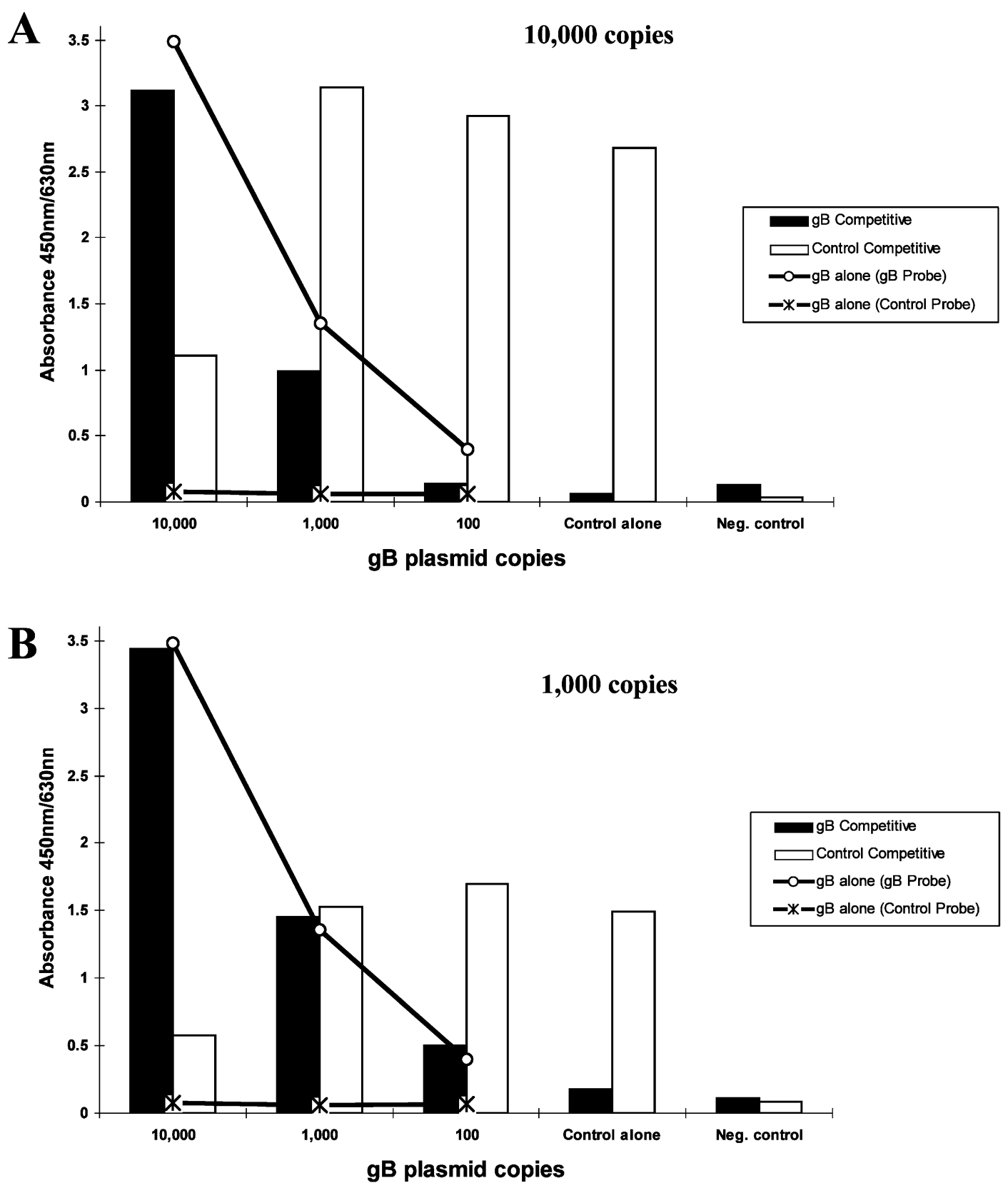

Fig. 3. Competitive PCR-ELISA with (A) 10000 or (B) 1000 copies of control plasmid in the presence of varying amounts of EHV-1 gB plasmid. EHV-1 gB plasmid copy number ranged from $10^{2}-10^{4}$ and was amplified alone (-o-) or in the presence of control plasmid (dark and light boxes) at the aforementioned amounts. The control DNP oligonucleotide probe was unreactive to gB-derived amplicons $(-\mathrm{x}-)$.

Based on PCR-ELISA results obtained, the minimum detection level was estimated at 100 copies of $\mathrm{gB}$ plasmid and 63 genome equivalents of EHV-1, respectively. The slightly higher sensitivity of detection observed with EHV-1 DNA may reflect the presence of non-specific carrier DNA in the preparation which prevents absorptive DNA loss onto tube walls. Comparable amplification efficiencies of $\mathrm{gB}$ target and control, at identical copy numbers, were evident which is a fundamental requirement of the competitive PCR assay. In order to determine the optimal copy number of control to be used in the competitive PCR-ELISA, competition assays were performed between the $\mathrm{gB}$ and control plasmids, respectively. Based on results obtained, 1000 copies of the control were found to be optimal for detection of EHV-1 gB amplicons without suppressing the sensitivity of target detection. Barber et al. (1999) recorded similar results using competitive internal control at 1000 copies in a PCR-ELISA to detect human cytomegalovirus blood samples of heart and lung transplant recipients.

The clinical utility of the competitive PCR-ELISA assay was assessed by the co-amplification of 1000 copies of control with EHV-1 positive/negative fetal 


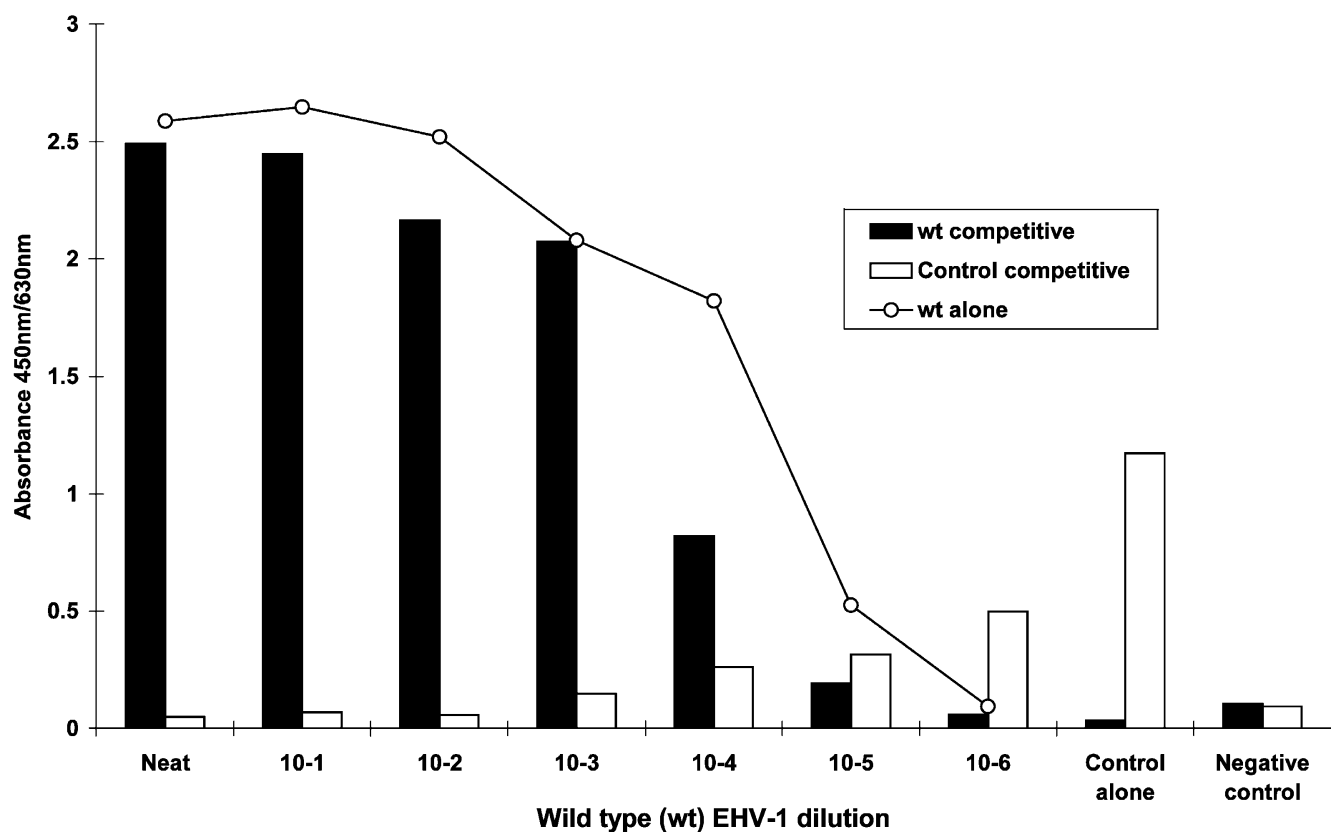

Fig. 4. Competitive PCR-ELISA analysis of wt EHV-1 at various dilutions. Log dilutions of purified EHV-1 DNA were amplified alone (-o - ) or co-amplified with 1000 copies of the control plasmid (dark and light boxes). It is apparent that high levels of EHV-1 DNA inhibit control amplification (Neat $-10^{-3}$ dilutions). Control amplification is evident at dilutions greater than $10^{-4}$ wt EHV-1 DNA. The PCR-ELISA cut-off value $(0.140)$ was calculated from the mean negative specimen absorbance +2 standard deviations $(0.095+2(0.0225) ; N=12)$.

tissue samples. Positive EHV-1 fetal tissue samples (S726-8, S685-7 and 835-7) resulted in the detection of high levels of EHV-1 amplicons by PCR-ELISA using gB-specific DNP oligonucleotide probes while negligible levels of control amplicons were recorded. These results demonstrate the competitive nature of the templates for the $\mathrm{P} 1-\mathrm{P} 2$ primers where the control was out-competed by the high concentrations of EHV-1 in positive tissue samples. All three EHV-1 negative fetal tissue samples (S611-3, S723-5 and 597-9) analysed by PCR-ELISA

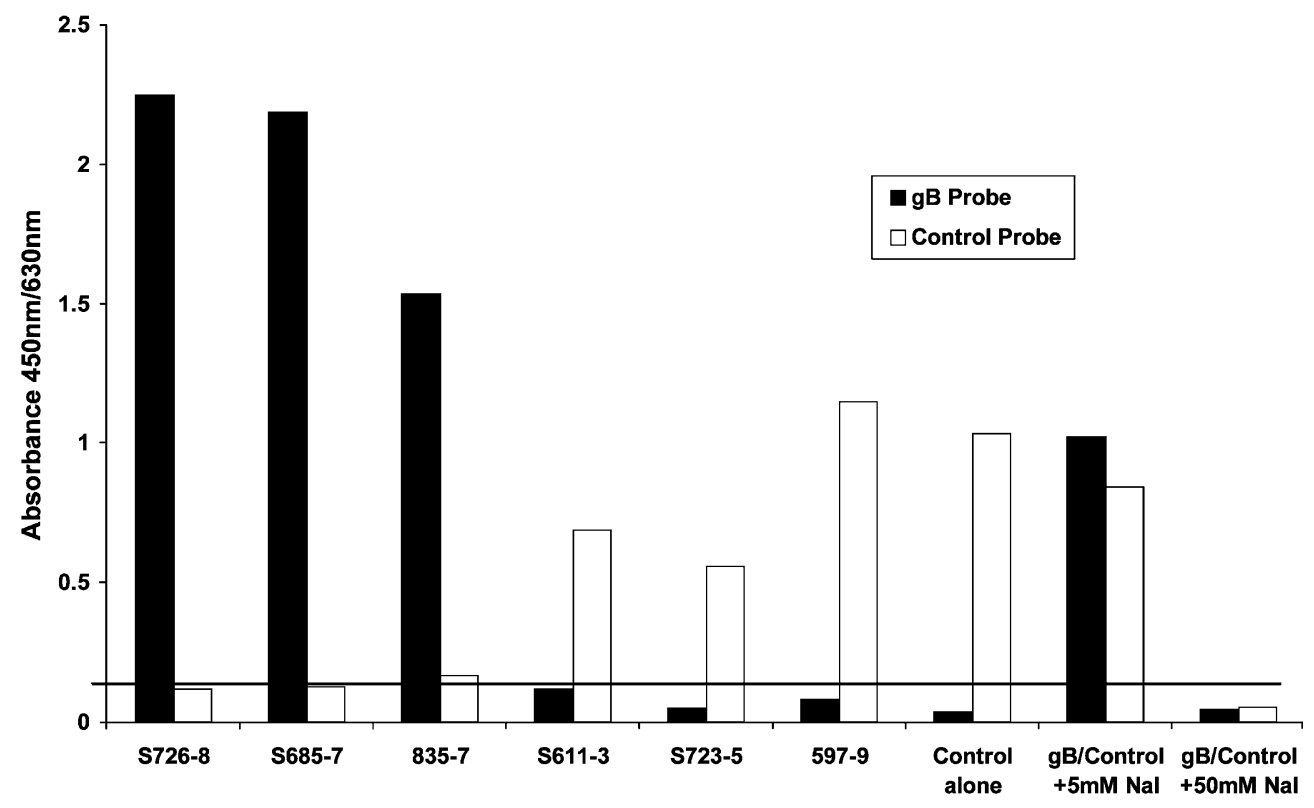

Equine foetal tissue specimens

Fig. 5. Evaluation of EHV-1 positive and negative clinical specimens by PCR-ELISA. Confirmed EHV-1 positive (S726-8, S685-7 and 835-7) and negative (S611-3, S723-5 and 597-9) tissue samples, by immunofluorescence and virus isolation, gave the expected result following blinded testing by PCR-ELISA. The effect of the PCR inhibitor, NaI, was investigated at 5 and $50 \mathrm{mM}$, respectively, in PCR reactions containing 1000 copies each of $\mathrm{gB}$ and control plasmid. No amplification was evident at $50 \mathrm{mM} \mathrm{NaI}$. The PCR-ELISA cut-off value (0.140) is indicated by the solid line. 
were control amplicon positive and negative for $\mathrm{gB}$ amplicons. Thus, the negative tissue samples were true negatives due to the successful amplification of the control. However, negative samples S611-3 and S723-5 in the competitive PCR-ELISA had significantly lower absorbance readings than that of sample 597-9 and 1000 copies of control alone. This suggests that there may be low concentrations of PCR inhibitors extracted from these tissue samples. To demonstrate the potential of the control in the PCR-ELISA to detect potent Taq polymerase inhibitors, the effect of $\mathrm{NaI}$ at different concentrations was investigated. The presence of high concentration of $\mathrm{NaI}(50 \mathrm{mM})$ completely inhibited the amplification of $\mathrm{gB}$ and control as determined by the absence of signals on the ELISA. The effect of reducing the concentration of inhibitor $(5 \mathrm{mM})$ relieved the inhibitory effect $\mathrm{NaI}$ and resulted in control detection in the PCR-ELISA.

Since EHV-1 is believed to persist following initial infection, the competitive PCR-ELISA developed here could be used to determine the actual viral load in the pregnant mare. Viral loads may correspond to the stage of disease and could be used as a marker for disease progression. It is currently unclear if serial surveillance can be used to monitor the progress of EHV-1 infections in horses and the EHV-1 PCR-ELISA presented here may provide a useful tool to investigate this situation.

In this study, the development of the first, internallycontrolled, competitive PCR-ELISA assay for the diagnosis of EHV-1 infection is described. The assay allows for multiple sample detection using end-stage, colourimetric detection of amplicons using gB typespecific DNP oligonucleotide probe hybridisation. The inclusion of a control eliminates the possibility of false negative EHV-1 results due to the co-extraction of PCR inhibitors. The design of this competitive PCR-ELISA diagnostic assay allows for the rapid and sensitive detection of EHV-1 in horses which, following further validation, may have significant potential for eliminating the occurrence of abortion storms in stud farms.

\section{Acknowledgements}

We are grateful to Enterprise Ireland for funding this work (Project code: ST/99/115). We also thank Dr J. Slater and Dr W. Eichhorn for supplying specimens for analysis.

\section{References}

Allen, G.P., Yeargan, M.R., Turtinen, L.W., Bryans, J.T., McCollum, W.H., 1983. Molecular epizootiologic studies of equine herpesvirus-1 infections by restriction endonuclease fingerprinting of viral DNA. Am. J. Vet. Res. 44 (2), 263-271.
Allen, G.P., Bryans, J.T., 1986. Molecular epizootiology, pathogenesis, and prophylaxis of equine herpesvirus-1 infections. Prog. Vet. Microbiol. Immunol. 2, 78-144.

Ballagi-Pordany, A., Klingeborn, B., Flensburg, J., Belak, S., 1990. Equine herpesvirus type 1: detection of viral DNA sequences in aborted fetuses with the polymerase chain reaction. Vet. Microbiol. 22 (4), 373-381.

Barber, L., Egan, J.J., Turner, A.J., Guiver, M., Woodcock, A.A., Yonan, N., Deiraniya, A.K., Fox, A.J., 1999. The development of a quantitative PCR ELISA to determine HCMV DNAaemia levels in heart, heart/lung and lung transplant recipients. J. Virol. Methods 82 (1), 85-97.

Borchers, K., Slater, J., 1993. A nested PCR for the detection and differentiation of EHV-1 and EHV-4. J. Virol. Methods 45 (3), $331-336$.

Courtney, B.C., Smith, M.M., Henchal, E.A., 1999. Development of internal controls for probe-based nucleic acid diagnostic assays. Anal. Biochem. 270 (2), 249-256.

Crabb, B.S., Studdert, M.J., 1995. Equine herpesviruses 4 (equine rhinopneumonitis virus) and 1 (equine abortion virus). Adv. Virus Res. 45, 153-190.

Drews, K., Bashir, T., Dorries, K., 2000. Quantification of human polyomavirus JC in brain tissue and cerebrospinal fluid of patients with progressive multifocal leukoencephalopathy by competitive PCR. J. Virol. Methods 84 (1), 23-36.

Gupta, A.K., Singh, B.K., Yadav, M.P., 1996. Application of polymerase chain reaction (PCR) for diagnosis of equine herpes virus-1 (EHV-1). Indian J. Exp. Biol. 34 (11), 1077-1080.

Kirisawa, R., Endo, A., Iwai, H., Kawakami, Y., 1993. Detection and identification of equine herpesvirus- 1 and -4 by polymerase chain reaction. Vet. Microbiol. 36 (1-2), 57-67.

Lawrence, G.L., Gilkerson, J., Love, D.N., Sabine, M., Whalley, J.M., 1994. Rapid, single-step differentiation of equid herpesviruses 1 and 4 from clinical material using the polymerase chain reaction and virus-specific primers. J. Virol. Methods 47 (1-2), 59-72.

Morris, C.M., Field, H.J., 1988. Application of cloned fragments of equine herpesvirus type-1 DNA for detection of virus-specific DNA in equine tissues. Equine Vet. J. 20 (5), 335-340.

Osterrieder, N., Hubert, P.H., Brandmuller, C., Kaaden, O.R., 1994. A touchdown PCR for the differentiation of equine herpesvirus type 1 (EHV-1) field strains from the modified live vaccine strain RacH. J. Virol. Methods 50 (1-3), 129-136.

Palfi, V., Christensen, L.S., 1995. Analyses of restriction fragment patterns (RFPs) and pathogenicity in baby mice of equine herpesvirus 1 and 4 (EHV-1 and EHV-4) strains circulating in Danish horses. Vet. Microbiol. 47 (1-2), 199-204.

Sharma, P.C., Cullinane, A.A., Onions, D.E., Nicolson, L., 1992. Diagnosis of equid herpesviruses -1 and -4 by polymerase chain reaction. Equine Vet. J. 24 (1), 20-25.

Studdert, M.J., Blackney, M.H., 1979. Equine herpesviruses: on the differentiation of respiratory from foetal strains of type 1. Aust. Vet. J. 55 (10), 488-492.

Studdert, M.J., Simpson, T., Roizman, B., 1981. Differentiation of respiratory and abortigenic isolates of equine herpesvirus 1 by restriction endonucleases. Science 214 (4520), 562-564.

Wagner, W.N., Bogdan, J., Haines, D., Townsend, H.G., Misra, V., 1992. Detection of equine herpesvirus and differentiation of equine herpesvirus type 1 from type 4 by the polymerase chain reaction. Can. J. Microbiol. 38 (11), 1193-1196.

Welch, H.M., Bridges, C.G., Lyon, A.M., Griffiths, L., Edington, N., 1992. Latent equid herpesviruses 1 and 4 : detection and distinction using the polymerase chain reaction and co-cultivation from lymphoid tissues. J. Gen. Virol. 73 (2), 261-268.

Zerbini, M., Gallinella, G., Manaresi, E., Musiani, M., Gentilomi, G., Venturoli, S., 1999. Standardization of a PCR-ELISA in serum samples: diagnosis of active parvovirus B19 infection. J. Med. Virol. 59 (2), 239-244. 